\title{
Upaya Meningkatkan Kemampuan Berbicara Bahasa Jepang melalui Metode Bermain Peran (Role Play)
}

\author{
Karjati Soemarmi
}

\author{
SMKN 3 Blitar \\ J1. Sudanco Supriyadi 24 Kota Blitar \\ Email: karjati_smkn3blt@yahoo.co.id
}

\section{Tersedia Online di \\ http://www.jurnal.unublitar.ac.id/ index.php/briliant}

\begin{tabular}{l}
\hline Sejarah Artikel \\
\hline Diterima pada 8 April 2017 \\
Disetuji pada 8 April 2017 \\
Dipublikasikan pada 1 Mei 2017 \\
Hal. 225-230
\end{tabular}

Kata Kunci:

kemampuan berbicara, bermain peran

\begin{abstract}
Abstrak: Jenis penelitian adalah penelitian tindakan kelas. Alasan untuk menggunakan penelitian tindakan adalah untuk meningkatkan metode pembelajaran yang digunakan guru. Hal ini dimungkinkan untuk meningkatkan kemampuan untuk berbicara dengan siswa dari menggunakan metode apapun yang cocok. Kemampuan untuk berbicara siswa dalam melihat hasil saat babak pertama penelitian masih belum baik. Rata-rata hasil adalah 63,4\%. Masih aspek tidak pengucapan yang baik dan ekspresi wajah dan gerakan tubuh adalah cara berbicara dan kemampuan wacana untuk memenuhi lawan dan situasi. Pada kedua kalinya penelitian, peningkatan kinerja dapat dilihat. Ratarata hasil akan $87,8 \%$.
\end{abstract}

Bahasa adalah alat komunikasi yang sangat penting untuk melakukan interaksi dengan orang lain. Hubungan interaksi tidak akan harmonis tanpa komunikasi. Dalam era globalisasi sekarang ini, bahasa asing memegang peranan penting untuk bisa berkomunikasi dengan masyarakat dari berbagai negara, salah satunya dalah Bahasa Jepang. Sekarang ini Bahasa Jepang menjadi salah satu bahasa yang banyak dipelajari oleh masyarakat dari berbagai negara. Dalam pembelajaran Bahasa Asing, terdapat empat kompetensi mendasar yang perlu dikuasai pembelajar, yaitu kemampuan mendengar, berbicara, membaca, dan menulis. Selain itu, pembelajaran bahasa perlu diarahkan kepada penggunaan bahasa dalam situasi yang real. Situasi yang real ini ditentukan oleh berbagai faktor seperti (1) peserta bicara, (2) tempat dan waktu pelangsungan interaksi berbahasa, (3) topik pembicaraan, (4) sarana pembicaraan,(5) tujuan pembicaraan, (6) perasaan yang berlangsung dalam pembicaraan (Sudjianto, 2010:99)

SMK Negeri 3 Blitar menyelenggarakan program pengajaran bahasa Jepang pada kompetensi keahlian Akomodasi Perhotelan, dan Tata Boga dengan tujuan dapat berguna sebagai bekal ketrampilan berbahasa asing di dunia Industri . Untuk mencapai tujuan tersebut guru menerapkan berbagai metode dalam pengajaran bahasa Jepang agar siswa mampu berkomunikasi dalam bahasa Jepang sehari-hari. Namun, pada kenyataanya, sebagian besar siswa masih menganggap bahwa Bahasa Jepang adalah pelajaran yang sulit. Mereka sulit memahami secara baik Siswa masih merasa takut untuk berbicara.

Dalam pengajaran Bahasa jepang pada umumnya siswa hanya menerima bahan pelajaran melalui informasi yang disampaikan oleh guru melalui metode ceramah, ekspositori, Tanya jawab atau metode lainnya yang kurang mengembangkan kemampuan berbicara siswa. Berhubungan dengan metode 
pembelajaran ini, penulis tertarik untuk mencoba mengadakan penelitian tentang salah satu metode pembelajaran yaitu metode bermain peran (role play). Metode bermain peran pada prinsipnya adalah metode untuk `menghadirkan` peran-peran yang ada di dunia nyata ke dalam suatu `pertunjukan peran` di dalam kelas yang kiemudian dijadikan sebagai bahan refleksi agar peserta/siswa dapat memberikan penilaian.

Misalnya menilai keunggulan dan kelemahan masing-masing dan kemudian memberikan saran dan pendapat bagi pengembangan peran-peran tersebut. Metode bermain peran (role play) mempunyai keistimewaan yaitu dapat melatih siswa dalam menghadapi situasi yang sebenarnya, melatih praktik berbahsa lisan secara intensif, dan memberikan kesempatan kepada siswa untuk mengembangkan kemampuan berkomunikasi. Selain itu, melalui metode bermain peran (role play) siswa lebih dapat memahami makna dari ungkapan dalam percakapan sehari-hari dibandingkan dengan hanya berlatih pengucapan atau hanya membaca dialog saja tanpa mempraktekkannya dengan bermain peran.

Berdasarkan uraian di atas, maka penulis mengajukan penelitian dengan judul Upaya Meningkatkan Kemampuan Berbicara Bahasa Jepang Melalui Metode bermain Peran (Role Play) pada Siswa kelas XII Jasa Boga 6 SMK Negeri 3 Blitar.

Metode pembelajaran yang sering dipakai untuk pembelajaran bahasa Jepang banyak jenisnya. Metode-metode tersebut masing- masing memiliki kelebihan - kelebihan serta kekurangan - kekurangannya yang menjadi karakteristiknya. Dengan demikian tidak ada metode yang dianggap paling baik atau paling jelek untuk pembelajaran keterampilan berbahasa Jepang. Metode pembelajaran keterampilan berbahasa Jepang yang baik adalah metode yang dipilih dan dipakai sesuai dengan situasi atau kondisi kegiatan pembelajaran, tujuan pembelajaran, materi pembelajaran yang diberikan, media pembelajaran yang dipakai, serta komponen- komponen pembelajaran lainnya. Pemakaian metode pembelajaran seperti itu dapat menimbulkan dan mengembangkan minat belajar serta meningkatkan kemampuan berbahasa Jepang.

Metode pembelajaran dalam penelitian ini merupakan upaya yang dilakukan oleh guru untuk menciptakan situasi pembelajaran yang menyenangkan, mudah dipahami dan mendukung bagi kelancaran belajar dan tercapainya tujuan untuk peningkatan kemampuan berbicara siswa.

$$
\begin{array}{cccc}
\text { Menurut Kida } & (2007: \quad 62) & \text { 「ロールプレイとは } \\
\text { 」決められた状沉や場面で、学習者がある役割になって、自分で表現を選 } \\
\text { んで、コミュニケーションする練習をロールプレイとよびます。 }
\end{array}
$$

Yang disebut bermain peran atau role play adalah latihan berkomunikasi yang dilakukan oleh pembelajar dengan peran tertentu dengan memilih ungkapan sendiri dengan situasi dan kondisi yang telah ditentukan.

Menurut Sumiati dan Asra (2007: 100), metode role play adalah bermain peran yang bertujuan menggambarkan, peristiwa masa lampau, masa kini maupun mendatang. Pemeran melakukan peranannya sendiri sesuai dengan daya khayal atau imajinasi tentang pokok yang diperankannya.

\section{METODE}

226 BRILIANT: Jurnal Riset dan Konseptual Volume 2 Nomor 2, Mei 2017 
Penelitian dilakukan di SMK Negeri 3 Blitar, Jl. Sudanco Supriyadi no. 24 Blitar, penelitian ini dilakasanakan pada bulan Agustus s/d bulan September 2016. Dirancang dalam 2 siklus. Satu siklus terdiri dari 2 pertemuan, dan waktu yang dibutuhkan setiap pertemuan adalah 2 x 45 menit.

Dalam penelitian tindakan kelas ini menggunakan alur yang dikembangkan oleh Kemmis dan MC Taggart dengan langkah-langkah (1). Perencanaan (planning), (2). Pelaksanaan (acting), (3). Pengamatan (observing), (4). Refleksi (reflecting) dan dilaksanakan secara siklus. Masing-masing siklus dimaksudkan untuk mengetahui kemampuan berbicara Bahasa Jepang siswa.

Perencanaan dilakukan berdasarkan pada hasil observasi dari subyek penelitian pada siswa yang mempunyai kemampuan berbicara bahasa Jepang yang rendah, dengan hanya berlatih menghafal dialog atau membaca contoh dialog saja tanpa mempraktekkannya dengan metode bermain peran (role play). Peneliti membuat Perencanaan Penelitian Tindakan Kelas ini sebagai berikut :

(1) Membuat RPP materi menyebutkan nama makanan dan minuman serta jumlahnya (2) Membuat lembar kegiatan siswa (3) Membuat lembar observasi siswa dan guru (4) Merumuskan langkah-langkah bermain peran (5) Menyiapkan cerita/materi yang akan dimainkan (5) Menyampaikan aspek yang dinilai

Pada tahap pelaksanaan Guru melaksanaan tahapan sesuai dengan RPP yang telah dirancang. Guru melakukan pengamatan aktifitas siswa, sedangkan guru partner sebagai observer melakukan pengamatan terhadap aktifitas guru.

Pada tahap observasi dilakukan antara peneliti dan pengamat/observer. Pada tahap ini dilakukan pengumpulan dan penghitungan hasil data pengamatan. Dari hasil pengamatan, baik oleh guru maupun observer, data dianalisa dengan analisa perhitungan yang sudah ditentukan oleh peneliti .

Pada tahap refleksi hasil obervasi yang telah diperoleh, didiskusikan oleh peneliti dan pengamat/observer untuk diambil suatu keputusan apakah hasil yang diharapkan sudah tercapai atau belum tercapai. Hasil refleksi akan digunakan sebagai pedoman untuk merencanakan siklus selanjutnya yang merupakan perbaikan dari siklus seblumnya.

Subyek penelitian adalah siswa kelas XII Jasa boga 6 . dengan jumlah siswa 23 orang, 19 orang siswa perempuan, dan 4 orang laki-laki. Kelas XII JB 6 termasuk dalam kategori kelas yang siswa nya masih kurang dalam kemampuan berbicara. Oleh karena itu peneliti berusaha menerapkan metode yang tepat untuk meningkatkan kemampuan berbicara siswa yaitu dengan metode bermain peran ( role play).

Dalam penelitian ini teknik pengumpulan data dilakukan dengan observasi, dokumentasi, dan tes lisan. Tes lisan diberikan pada Siklus 1, 2 melalui metode bermain peran ketika proses pembelajaran berlangsung. Penilaian menggunakan teknik penskoran, sehingga skor yang diperoleh dari masingmasing deskriptor dijumlahkan dan hasilnya disebut jumlah skor. Selanjutnya dilakukan analisis prosentase nilai rata-rata dengan cara membagi jumlah skor dengan skor maksimal dikalikan $100 \%$.

Instrumen yang digunakan dalam penelitian ini meliputi: Lembar observasi metode bermain peran (role play) untuk guru dan siswa, serta tes yang digunakan untuk mengukur kemampuan Bahasa Jepang siswa tiap siklus.

227 BRILIANT: Jurnal Riset dan Konseptual

Volume 2 Nomor 2, Mei 2017 


\section{HASIL}

\section{Hasil Siklus I}

Pertemuan pertama (2x 45 menit), kegiatan pembelajaran pada pertemuan ini adalah persiapan meliputi (1) Menyampaikan materi yang akan dipelajari hari ini, (2) Menyampaikan tujuan pembelajaran hari ini dalam meningkatkan kemampuan berbicara yang akan dicapai dengan metode bermain peran (role play) (3) Guru memberi contoh percakapan, (4) Menggali informasi dari siswa tentang kosa kata makanan /minuman jepang, (5) Bersama siswa mempelajari kosa kata baru tentang makanan/minuman dengan menunjukkan kartu bergambar, guru mengucapkan siswa memperhatikan dan mengulangi (6) Siswa Mempelajari kalimat/ungkapan yang digunakan untuk memesan makanan /minuman di restoran. Kemudian kegiatan meliputi: (1) Guru membentuk kelompok dan membimbing siswa untuk berlatih percakapan bersama dengan kelompoknya, (2) Guru menjelaskan langkah-langkah bermain peran serta materi bermain peran dan meminta siswa untuk berperan sebagai pembeli/tamu dan sebagai pelayan, (3) Siswa berlatih bersama pasangannya seperti contoh yang diberikan oleh guru, (4) Setelah selesai berlatih, guru membimbing siswa untuk membuat naskah untuk ulangan lisan dengan metode bermain peran, dengan tema memesan makanan/minuman di restoran . Kemudian selanjutnya adalah penilaian yaitu Guru mengevaluasi hasil kerja siswa dengan memberikan tanggapan/kesan terhadap metode bermain peran.

Berdasarkan pengamatan yang telah dilakukan oleh peneliti dan kolaborator, maka pada pertemuan kedua siklus 1 ini, metode bermain peran ada kelompok yang sudah dapat berjalan dengan baik, tetapi ada juga yang masih malu-malu dan belum bersungguh-sungguh, pada sklus 1 ini kelemahan/kekurangan yang ditemukan, seperti pelafalan/intonasi yang masih kurang betul pada beberapa ungkapan dan penekanan kalimat Tanya, serta kesesuain gerakan/ekspersi dan ucapan akan diperbaiki pada pertemuan berikutnya di siklus 2 .

Berdasarkan hasil pengamatan pada siklus 1, kemampuan berbicara Bahasa Jepang siswa dari 23 siswa, $17.39 \%$ masih kurang, 56.52 \% cukup dan $26.08 \%$ baik. Peneliti dan kolaborator setelah mengetahui kemampuan berbicara siswa sebagian besar masih kurang, maka peneliti ingin mengetahui secara lebih lanjut tentang kesulitan yang dihadapi siswa dalam meningkatkan kemampuan berbicara bahasa Jepang. Oleh karena itu peneliti dan kolabotor perlu melaksanakan perbaikan pada siklus 2 dengan melihat kekurangan-kekurangan yang ditemukan pada siklus 1 .

\section{Hasil Siklus II}

Pelaksanaan tindakan pada siklus II ini dilaksanakan sebanyak 2 x pertemuan@ @ 45 menit. Aspek -aspek yang masih rendah terutama pada pelafalan, kesesuaian antara ekspresi dan ucapan serta kelancaran berbicara perlu ditingkatkan. Prosedur penelitian pada siklus II ini dilaksanakan bertahap sebagai berikut: (1) persiapan yaitu: menyampaikan materi, tujuan, (2) kegiatan yaitu meliputi: latihan percakapan, membuat naskah percakapan , (3) penilaian yang 
meliputi: evaluasi dari guru, bersama siswa menyimpulkan kegiatan , pengumpulan naskah.

Berdasarkan pengamatan yang telah dilakukan oleh peneliti dan kolaborator, maka pada pertemuan pertama siklus 2 ini, siswa sudah dapat berlatih menyusun kalimat sesuai pola yang benar, demikian pula dalam mengucapkan kosa kata /ungkapan-ungkapan yang panjang sudah baik.. Dalam berlatih bermain peran sebagian besar kelompok sudah dapat berjalan dengan baik. Sudah banyak peningkatan dalam memahami arti dari ungkapan sehingga dalam praktek kesesuaian antara gerakan/ekspresi dengan ucapan dapat berjalan dengan baik.

Berdasarkan pengamatan pada siklus 2 , terjadi peningkatan untuk kemampuan berbicara yang sangat baik yaitu, seperti tampak pada tabel di atas : yang mendapat nilai baik $47.82 \%$ dan sangat baik sebanyak $52.17 \%$, mendapat nilai cukup sebanyak $0 \%$, sedangkan nilai kurang sebanyak $0 \%$. Berdasarkan hasil tersebut, kemampuan berbicara dari sebagian besar siswa kelas XII JB 6 SMKN 3 Blitar adalah baik.

Berdasarkan pengamatan pada siklus 1 kemampuan berbicara siswa ratarata skor adalah 63.4 dan setelah siklus II mengalami peningkatan rata-rata skor adalah 87.7, sehingga mengalami perubahan $24.3 \%$.

\section{PEMBAHASAN}

Berdasarkan pengamatan mengenai kemampuan berbicara Bahasa Jepang siswa kelas XII JB 6 SMKN 3 Blitar, yang meliputi beberapa aspek yaitu aspek penggunaan tata bahasa yang tepat, ketepatan intonasi/ pelafalan Bahasa Jepang, kesesuaian antara gerakan/ekspresi dengan ucapan, serta kelancaran berbicara pada siklus 1 masih kurang. Banyaknya prosentase jumlah siswa yang kemampuan berbicaranya masih kurang, membuat peneliti berpikir untuk mencari pemecahan masalahnya . Berbagai macam motivasi dilakukan untuk meningkatkan kepercayaan diri siswa untuk berani dan aktif berbicara, tetapi hal itu tidaklah cukup. Akhirnya peneliti memikirkan metode apa yang tepat untuk meningkatkan kemampuan berbicara siswa. Menurut Sumiati dan Asra (2008: 92) setiap metode pembelajaran mempunyai keunggulan dan kelemahan masingmasing, Metode pembelajaran mempunyai fungsi untuk mengarahkan materi pembelajaran. Pada materi pembelajaran kali ini adalah menyebutkan nama makanan dan minuman serta jumlahnya agar dapat memesan makanan dan minuman di restoran, dengan menggunakan metode bermain peran ( role play) siswa lebih mudah untuk memahami arti dari ungkapan/kalimat yang diucapkannya. Sehingga siswa dapat berbicara dengan baik sesuai dengan peran yang dimainkannya. Setelah melakukan pengamatan pada siklus I, peneliti menemukan beberapa kekurangan yang menyebabkan kemampuan berbicara ratarata siswa kelas XII JB 6 masih kurang. Oleh karena itu peneliti memperbaikinya dengan melalui tahapan pertemuan ke 1 dan 2 pada siklus II.

Pada siklus II siswa terlihat lebih percaya diri dalam mengucapkan ungkapan yang sulit dan panjang, karena berkali-kali melakukan latihan bersama pasangannya untuk berperan sebagai tamu dan pelayan. Siswa lebih lancar dalam berbicara dan memahami arti dari kalimat yang diucapkannya.

Dari hasil pengamatan siklus I kemampuan siswa dalam berbicara tampak dari nilai ulangan lisan siswa rata-rata masing kurang yaitu $63.4 \%$,

229 BRILIANT: Jurnal Riset dan Konseptual

Volume 2 Nomor 2, Mei 2017 
kemudian meningkat setelah melalui tahapan pada siklus II menjadi $87.7 \%$ yang berarti ada peningkatan rata-rata $24.3 \%$.

Setelah melaksanakan penelitian dalam 2 siklus, penerapan metode bermain peran (role play) untuk meningkatkan kemampuan berbicara siswa kelas XII JB 6 SMKN 3 Blitar dapat berhasil dengan baik.

\section{KESIMPULAN}

Berdasarkan hasil deskripsi dari hasil penelitian dan pembahasan yang telah diuraikan pada bab IV bahwa kemampuan berbicara siswa dapat ditingkatkan dengan melalui metode bermain peran (role play). Kemampuan berbicara siswa pada siklus I menunjukkan masih kurang terutama pada aspek pengucapan intonasi/pelafalan, kesesuaian gerakan/ekspresi dengan ucapan, dan kelancaran berbicara. Untuk penguasaan tata bahasa masih dalam kategori cukup baik. Tetapi setelah adanya tindakan pada tahapan siklus II, kemampuan berbicara siswa mengalami peningkatan yang lebih baik, dengan ditunjukkan adanya kenaikan nilai rata-rata sebesar $24.3 \%$. Dengan demikian dapat disimpulkan bahwa Penggunaan metode bermain peran (role play) dapat meningkatkan kemampuan berbicara bahasa Jepang pada kelas XII JB 6 SMKN 3 Blitar. Menunjukkan adanya peningkatan kemampuan berbicara siswa hal itu ditunjukkan dari hasil penelitian tindakan kelas siklus I kemudian dilanjutkan pada siklus II yaitu peningkatan rata-rata nilai sebesar $24.3 \%$.

\section{SARAN}

Saran yang dapat penulis kemukakan adalah: (1) Guru bahasa Jepang dapat terus mengembangkan metode bermain peran (role play) dalam materimateri yang lain dengan cara yang menyenangkan agar siswa merasa lebih percaya diri dalam berbicara, sehingga kemampuan berbicara menjadi lebih baik. 2) Bagi Peneliti yang lain, penelitian ini bisa dijadikan bahan referensi, serta dikembangkan dengan materi pembelajaran yang lainnya.

\section{DAFTAR PUSTAKA}

Asrori, Mohammad. 2007. Penelitian Tindakan Kelas. Bandung: Wacana Prima

Danasasmita, W. 2009. Metodologi Pembelajaran Bahasa Jepang. Bandung: Rizki press

Kida, Mari, dkk. 2007. Hanasu Koto o Oshieru. Tokyo: The Japan Foundation.

Sudjianto. 2010. Motodologi Pembelajaran Ketrampilan Berbahasa Jepang. Bekasi: Kessaint Blanc.

Sumiati., \& Asra. 2008. Metode Pembelajaran. Bandung: Wacana Prima.

Sutedi, Dedi. 2009. Penelitian Pendidikan Bahasa Jepang. Bandung: Humaniora.

Tarigan, Henry Guntur. 2015. Berbicara Sebagai Ketrampilan Berbahasa. Bandung: Angkasa. 